\title{
Disturbance and recovery of a deep-water Caribbean seagrass bed ${ }^{*}$
}

\author{
Susan L. Williams \\ Department of Botany, and Friday Harbor Laboratories, University of Washington, 620 University Road, Friday Harbor, \\ Washington 98250 , USA
}

\begin{abstract}
The seagrass community in a deep-water $(20 \mathrm{~m})$ submarine canyon on St. Croix, US Virgin Islands showed strong seasonal changes in abundances (50 to $90 \%$ of yearly maxima) of major plant species in response to predictable winter conditions of low light and storms. Major species were the seagrass Halophila decipiens and the green macroalga Halimeda incrassata. Virtual elimination of the seagrass occurred following particularly severe storms; the alga was more resistant. Seagrass and alga regained their pre-disturbance biomass or abundance within 6 to 8 mo after major storms. Addition of nutrients to the sediments had no effect on the growth or recolonization rate of the alga. The rates of recolonization of the alga and seagrass were controlled by light availability in winter. Dynamics of disturbance and recovery in this deep-water seagrass bed are very different from other Caribbean seagrass communities in shallow waters, which are more resistant to storms of similar magnitude but once disturbed take many years for recovery. The deep-water seagrass bed is an example of a tropical community that is structured by seasonal abiotic disturbances and physiological extremes, as are many temperate marine communities.
\end{abstract}

\section{INTRODUCTION}

In shallow waters, seagrasses of the genus Halophila are considered colonizer species and are typically found in disturbed habitats or habitats where low light/ high turbidity conditions limit the distribution of other seagrass species (den Hartog 1971, Lipkin 1979, Phillips \& Lewis 1983, Birch \& Birch 1984, Kirkman 1985). In waters deeper than $10 \mathrm{~m}$, Halophila spp. often form extensive beds with rhizophytic green macroalgae of the order Caulerpales. Although the biomass and thus areal productivity of Halophila spp. is low compared to most other tropical seagrasses (Lipkin 1979, Zieman \& Wetzel 1980, Josselyn et al. 1986), the turnover of Halophila decipiens is rapid and can provide important sources of organic matter and habitat for other organisms (Josselyn et al. 1983, 1986). Nevertheless, there have been no long-term studies of deep water Halophila spp. beds. In general, long-term studies of tropical marine plant communities are few.

Here I present results of a long-term study ( $>2 \mathrm{yr}$ ) of

\footnotetext{
- Contribution No. 170 from the West Indies Laboratory and NURP-FDU-J-459 from the National Undersea Research Program
}

a deep-water plant community dominated by Halophila decipiens and the calcareous green macroalga Halimeda incrassata. The study site was the floor of Salt River submarine canyon on the north shore of St. Croix, US Virgin Islands. At least 7 species of the macroalga Caulerpa also occur but in lower abundance (Williams et al. 1985a). Other benthic macroalgae (excluding epiphytes) are uncommon.

Plants growing on the canyon floor are subject to environmental stress and frequent disturbance. Stress, defined sensu Grime (1977) as a factor that reduces the potential for growth, is caused by low light and unstable sediments (Williams et al. 1985a, Josselyn et al. 1986). Disturbance is a process that removes biomass (Grime 1977); storms, resultant surge, currents, and sediment redistribution are the most intense disturbances in Salt River canyon. Although grazers are likely responsible for the narrow band of unvegetated sediments between the canyon walls (which provide coral reef habitat) and the canyon floor, they are very rare on the canyon floor proper where no refuge is available (Williams et al. 1985a, Williams, pers. obs. of $540 \mathrm{~h}$ ).

The study describes disturbance and subsequent recovery patterns in the deep-water seagrass bed in Salt River canyon. The results are compared to previ- 
ous studies on Caribbean seagrass beds in shallow waters where the seagrass Thalassia testudinum typically dominates the plant community. Patterns of disturbance and recovery in such shallow water seagrass beds are relatively well-studied in contrast to those in deep water (den Hartog 1971, Kelly et al. 1971, Patriquin 1975, Zieman 1976, Williams 1981, 1985).

\section{METHODS}

The floor of Salt River submarine canyon $\left(17^{\circ} 47^{\prime} \mathrm{N}_{i}\right.$ $64^{\circ} 45^{\prime} \mathrm{W}$ ) is characterized by unstable sand sediments with numerous ripple marks and a high degree of bioturbation (Williams et al. 1985a). Currents in the canyon are variable in speed and direction but generally weak $\left(<0.5 \mathrm{~cm} \mathrm{~s}^{-1}\right)$ except during storms (see 'Results'; Josselyn et al. 1983). The study site was exposed to open ocean swells, and surge was usually evident at a depth of $30 \mathrm{~m}$.

In March 1984, I established a sampling grid 11 by $11 \mathrm{~m}$ at $20 \mathrm{~m}$ depth on the canyon floor. Twenty permanent $0.25 \mathrm{~m}^{2}$ plots were assigned randomly in the grid for monthly monitoring of Halimeda incrassata. Individual thalli in the plots were identified with a small numbered plastic strip tied at the base of the upright portion. 'New' thalli were marked after they recruited into the permanent plots between sampling times.

Immediately following Tropical Storm 'Klaus' ( 6 to 13 Nov 1984), 10 of the original plots were assigned randomly to a fertilization treatment in order to test the hypothesis that the rate of recolonization was nutrientlimited. Each fertilized plot received $24 \mathrm{~g} \mathrm{~N}$ as $\mathrm{NH}_{4}^{+}$and $5 \mathrm{~g} \mathrm{P}$ as $\mathrm{P}_{2} \mathrm{O}_{5}$ in the form of solid time-released fertilizer spikes (Jobes 'Tree Spikes', Lexington, KY, USA) placed monthly in the sediments in the center of the plot to a depth of $15 \mathrm{~cm}$. Fertilization of the sediments rather than the water column was appropriate because seagrasses and rhizophytic algae absorb sediment nutrients through roots and rhizoids respectively (McRoy \& McMillan 1977, Williams 1984). I determined the fertilizer mass to use in a preliminary experiment in a different but similar area of the canyon; double the amount used here killed plants. The numbers of thalli in fertilized and control treatments were compared over time using 2 -way analysis of variance (ANOVA).

I sampled sediment porewaters for nutrient concentrations using miniature diffusion chambers (Williams et al. 1985b) because the coarse sediments were not amenable to coring or inserting larger diffusion chambers. Chambers were filled with 0.45 um Milleporefiltered, de-oxygenated seawater, buried in the upper layer of sediment, and allowed to equilibrate with porewaters for $14 \mathrm{~d}$ before retrieval. Chambers were placed haphazardly within a $0.25 \mathrm{~m}^{2}$ area around a fertilizer spike and also in control areas without fertilizer. I also placed 2 chambers on opposite sides of a spike at $5 \mathrm{~cm}$ intervals to a radius of $20 \mathrm{~cm}$ to determine the effective radius of fertilization. Porewater analysis followed methods of Williams et al. (1985b). Because the sediments were reducing and I assumed that nitrogen was limiting to plant growth, I measured ammonium, although recent evidence shows that under some circumstances, phosphorus limits the growth of some macroalgae and perhaps a seagrass (Short et al. 1985, LaPointe 1986, 1987). However, the fertilizer spikes raise sediment phosphorus as well as nitrogen concentrations (Williams 1987).

The growth of fertilized versus unfertilized Halimeda incrassata was determined during Hydrolab Mission \# 84-14 from 26 Nov to 6 Dec 1984. Hydrolab is an underwater laboratory and saturation diving facility. A total of 30 plants were selected haphazardly from within fertilized plots. Likewise, 30 control plants were selected at least $2 \mathrm{~m}$ away from the fertilized plots and outside of the permanent unfertilized plots. Growth was measured by marking the terminal segment of all branches on a plant with a $1 \times 5 \mathrm{~mm}$ aluminum tag and counting all new segments 5 d later. The control plants were removed, separated into new versus old growth, decalcified in $20 \%$ glacial acetic acid, briefly rinsed in freshwater, dried at $80^{\circ} \mathrm{C}$, and weighed. A regression between the number of segments and dry weight ( $\mathrm{n}=60 ; \mathrm{r}=0.96$ ) was calculated and used to estimate the biomass of new growth of the unsacrificed fertilized plants. Growth rates of fertilized versus control plants were compared using a Student's t-test.

At each sampling time, $201.0 \mathrm{~m}^{2}$ areas of the grid were randomly selected for collection of biomass of Halophila decipiens. Plots established for monitoring Halimeda incrassata were left undisturbed. No areas were resampled for at least 5 mo. Above plus below ground biomass was taken by tossing a plexiglass ring corer $\left(0.0165 \mathrm{~m}^{2}\right)$ into each $1 \mathrm{~m}^{2}$ area and collecting all $H$. decipiens within the ring. Sediments were washed from the seagrass, and visible epiphytes (primarily a summer phenomenon) were removed. The material was rinsed briefly in freshwater, dried at $80^{\circ} \mathrm{C}$, and weighed

Water temperature $1 \mathrm{~m}$ above the sediments was recorded with a Ryan thermograph. Terrestrial and submarine photosynthetically active radiation (PAR) were measured using a LI-COR terrestrial cosinecorrected quantum sensor, a $4 \pi$ underwater quantum sensor, a Solar Monitor, and integrating quantum meter. From January 1985 through May 1986, incoming irradiance was integrated at hourly intervals throughout the daily light period. The extinction coeffi- 
cient $\mathrm{k}$ was derived from vertical profiles of submarine light using the equation

$$
\mathrm{I}_{\mathrm{z}}=\mathrm{I}_{0} \mathrm{e}^{-\mathrm{kz}},
$$

where $I_{z}=$ quantum irradiance at depth $z_{;} I_{0}=$ quantum irradiance at the surface of the water.

The portion of the daily light period in which light exceeds the saturation irradiance, i.e. the minimum irradiance at which the maximum photosynthetic rate is achieved, is defined as $\mathrm{H}_{\text {sat }}$ (Dennison \& Alberte 1985). $H_{\text {sat }}$ predicts the effect of light on seagrass growth better than does light intensity alone (Dennison \& Alberte 1985, Dennison 1987). Here, $\mathrm{H}_{\text {sat }}$ is defined as the portion of the daily light period in which irradiance at $20 \mathrm{~m}$ water depth exceeded $100 \mu \mathrm{mol}$ quanta $\mathrm{m}^{-2} \mathrm{~s}^{-1}$. This intensity was chosen because the saturation irradiance of photosynthesis of Halophila spp. is 70 to $175 \mu \mathrm{mol}$ quanta $\mathrm{m}^{-2} \mathrm{~s}^{-1}$ (Josselyn et al. 1986, Dennison 1987). Previous experiments in Salt River canyon (Williams \& Dennison unpubl.) determined that the growth of Halophila decipiens is no longer dependent on light (i.e. growth was 'light-satu- rated') when $\mathrm{H}_{\text {sat }}$ was $\geq 9 \mathrm{~h}$; below $9 \mathrm{~h}$, growth is lightlimited. Using the maximum $\mathrm{k}$ measured, $\mathrm{H}_{\text {sat }}$ was determined during the period when hourly integrations of surface irradiance were made.

\section{RESULTS}

The 40 knot winds of Tropical Storm 'Klaus' were a major disturbance to the plants in Salt River canyon. During the storm, waves $3 \mathrm{~m}$ high broke on Salt River barrier reef (at the head of the canyon) and currents up to 2 knots were measured in the canyon (Wood, pers. comm.). Transmittance of light through the water was reduced to zero for several days. The upper $0.6 \mathrm{~m}$ of sediment was removed down-canyon in a sheet flow, dislodging cement blocks that anchored equipment. Surge whipped upright macroalgal thalli back and forth from prone positions on the sediment surface. Plants were uprooted, buried, and broken. At the end of the storm, marine sediments were covered with a thin layer of brown, terrestrially-derived sediment and


Fig. 1 Halimeda incrassata. Abundance of old plus new thalli at $20 \mathrm{~m}$ water depth in the permanent quadrats. Mean values \pm 1 standard deviation for unfertilized plots; mean values for fertilized plots. Heavy arrow: Tropical Storm 'Klaus'; small arrows: other storms
Fig. 2. Halophila decipiens. Biomass at $20 \mathrm{~m}$ water depth. Mean values \pm 1 standard deviation. Heavy arrow: Tropical Storm 'Klaus'; small arrows: other storms. (o) data taken from Josselyn et al. 1986 
other debris and were littered with sponges and gorgonians dislodged from the reef and canyon walls.

Halimeda incrassata declined to $58 \%$ of its density of the previous summer but was more resistant to the disturbances than were the other plants (Fig. 1). Greater than $99 \%$ of Halophila decipiens and also Caulerpa spp. was eliminated from the shallow apex of the canyon at $15 \mathrm{~m}$ to at least $23 \mathrm{~m}$. The biomass of $H$. decipiens declined from $>5 \mathrm{~g}$ to $<1 \mathrm{mg} \mathrm{m}^{-2}$ (Fig. 2). Increased resistance of $H$. incrassata resulted from its deeper $(10 \mathrm{~cm})$, more massive rhizoidal holdfast compared with the fine, superficial rhizomes and roots $(5 \mathrm{~cm}$ long) of the seagrass.

In each successive year, a less intense storm disturbed the plant populations in Salt River canyon. In 1985, a cyclonic storm occurred in October and in November. The loss of Halophila decipiens after these storms was less severe than after 'Klaus'; more and larger patches of the seagrass were left (Fig. 2). Halimeda incrassata lost only $27 \%$ of its pre-storm abundance (Fig. 1). However, most of the upper portions of the thalli were lost. Many thalli were almost completely buried by ripple marks $30 \mathrm{~cm}$ high. In December 1986, large swells from a non-cyclonic storm virtually eliminated $H$. decipiens, similarly to 'Klaus', but the abundance of $H$. incrassata changed little. The abundance of $H$. incrassata declined to $50 \%$ of the summer maximum just prior to the storm. Although bioturbation by macrofauna is stressful to the plants (Williams et al. 1985a), it is not responsible for the observed seasonal declines in plant abundances because bioturbation also declines during the winter when animals are less active and conch (Strombus gigas) remain buried (M. Coulston pers. comm., Williams pers. obs.)

Within 6 mo after 'Klaus', Halimeda incrassata regained its pre-storm abundance but declined thereafter (Fig. 1). Both loss of mature thalli and reduced recruitment of new thalli occurred (Fig. 3). Apparently regrowth was by vegetative propagation; I observed only a single individual with gametangia, and Halimeda spp. lack zoospores. Halimeda spp. are clonal plants that propagate well from rhizoidal filaments, buried branches, and holdfasts (Hillis-Colinvaux 1980, Williams pers, obs.). For several reasons, it is unlikely that the initially high recruitment of the alga came from vegetative propagules washed into the canyon from shallow water during the storm. The peak of recruitment occurred 6 mo later and correlated with increased light availability. By this time, individuals washed into the canyon would have completed their lifespan; marked individuals typically died within 4 to $8 \mathrm{mo}$. Also, I have observed no dormancy in Halimeda spp. Viable plants that are buried regenerate new upright thalli within $1 \mathrm{mo}$.
Ammonium concentrations in sediment porewaters were 4 times higher in fertilized versus control areas (1-sided t-test, $p<0.001)$. Maximum ammonium concentrations in fertilized sediments reached $177 \mu \mathrm{M}$ in fertilized versus $9.8 \pm 3.2 \mu \mathrm{M}$. Mean ammonium concentrations ( \pm 1 standard deviation) were $38 \pm 46 \mu \mathrm{M}$ in unfertilized sediments. These concentrations were reasonable estimates of the average concentrations because they were taken midway between successive applications of fertilizer. Concentrations of $36 \mu \mathrm{M}$ occurred at least $20 \mathrm{~cm}$ from the point source. I did not measure soluble phosphate concentrations. However, in a similar study in a shallow seagrass bed on $\mathrm{St}$. Croix, I demonstrated that an equal mass of the same fertilizer spikes raised soluble phosphate concentrations over 200 times ambient concentrations (Williams 1987). There is no reason that phosphorus would not diffuse from the fertilizer spikes in Salt River canyon. Although phosphate is strongly adsorbed to pure calcite and aragonite crystals in the laboratory (DeKanel \& Morse 1987), this process is dependent on the concentration of soluble phosphate. Furthermore, carbonate sediments of coral reefs and seagrass beds are not purely carbonate but contain organic matter (Williams et al. 1985b) and also significant soluble phosphorus pools (Entsch et al. 1983).

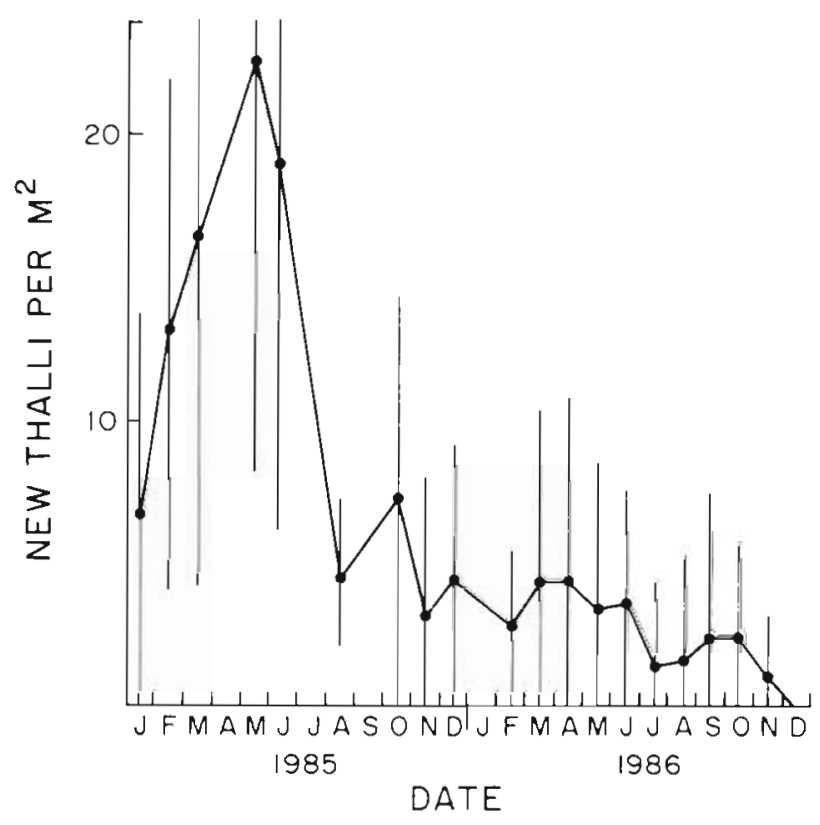

Fig. 3. Halimeda incrassata. Recruitment of new upright thalli in permanent quadrats. Mean values \pm 1 standard deviation

Increased sediment nutrients had no effect on the abundance (2-way ANOVA, $p>0.10$ ) or growth (2-tailed t-test, $p>0.10$. Table 1) of Halimeda incrassata, providing indirect evidence for light limita- 
Table 1. Halimeda incrassata, Growth in Salt River canyon, St. Croix, from 30 Nov to $5 \mathrm{Dec} 1984$. Values $=$ means \pm 1 standard deviation

\begin{tabular}{|c|c|c|}
\hline Sample size & $\begin{array}{c}\text { Fertilized } \\
23\end{array}$ & $\begin{array}{c}\text { Control } \\
22\end{array}$ \\
\hline $\begin{array}{l}\text { New segments plant }{ }^{-1} \mathrm{~d}^{-1} \\
\mu \mathrm{g} \text { (dry plant) })^{-1} \mathrm{~d}^{-1} \\
\% \text { Plants not growing }\end{array}$ & $\begin{array}{c}1.0 \pm 1.0 \\
385 \pm 427 \\
39\end{array}$ & $\begin{array}{c}0.8 \pm 1.4 \\
311 \pm 520 \\
59\end{array}$ \\
\hline
\end{tabular}

tion. Halophila decipiens in the unfertilized areas was not qualitatively different in or around the fertilized plots.

Halophila decipiens recovered its pre-'Klaus' biomass within 6 to 8 mo or conceivably earlier as no measurements were taken between Jan and Apr 1985 (Fig. 2). More rapid recovery after subsequent storms occurred because more seagrass remained to recolonize (Fig. 2). Recovery occurred through vegetative extension and coalescence of patches of seagrass but sexual reproduction also may have played a role. Flowers and mature fruits were abundant in each biomass collection, and seedlings have been found in the canyon (Josselyn pers. comm.).

Changes in plant abundances rather than species diversity and composition occurred following disturbance in Salt River canyon where species diversity is low. The canyon is below the depth limits of Halodule wrightu, Syringodium filiforme, and Thalassia testudinum (Phillips \& Lewis 1983), species that typically form a successional series in shallow waters (Patriquin 1975, Zieman 1976, den Hartog 1977). Seeds and seedlings of $S$. filiforme and $T$. testudinum and vegetative pieces of these species and $H$. wrightii did not survive more than 1 mo in the canyon (pers. obs.). S. filiforme and $T$. testudinum transplanted into the canyon in summer did not survive past September (Dennison \& Williams, unpubl.), presumably due to insufficient light.

The long-term decline in Halimeda incrassata in Salt River canyon was correlated with increased coverage of the sediments by Halophila decipiens. Although biomass of the seagrass recovered each year, the plant community appeared patchy until the fall of 1986 when $H$. decipiens covered the sediments almost completely, as it had before Tropical Storm 'Klaus' and when Caulerpa spp. finally regained their former abundance and diversity.

Within the long-term trends described above, plant abundances declined seasonally during October through February when light decreased (Figs. 1, 2 and 4) and swells increased, intensifying disturbance of the sediments (Williams et al. 1985a). The extinction coefficient $\mathrm{k}$ at $20 \mathrm{~m}$ ranged from 0.005 to 0.023 . From April through August, $\mathrm{H}_{\text {sat }}$ was $\geq 9 \mathrm{~h}$, sufficient for growth of Halophila decipiens (Table 2). From October through February, the growth of $H$. decipiens was light-limited when $\mathrm{H}_{\text {sat }}$ was $<9 \mathrm{~h}$ for 14 to $35 \%$ of the time. The seasonal difference in temperature of $2{ }^{\circ} \mathrm{C}$ was probably insufficient to cause the seasonal changes in abundance. Seasonal changes were more pronounced in $H$. decipiens than Halimeda incrassata. In addition to being more resistant to storms, the alga may tolerate low light better than the seagrass. H. incrassata grew deeper than the $40 \mathrm{~m}$ limit of the seagrass. Because storms occurred each year, their effect cannot be fully separated from low light in winter.

\section{DISCUSSION}

Temporal variation in the abundance of seagrasses is not well-documented in areas undisturbed by man, particularly in the tropics, but natural temporal varia-



Fig. 4. Incoming solar irradiance (PAR), Salt River canyon, St. Croix. Mean values \pm 1 standard deviation. Missing data due to malfunction or factory calibration of sensors or meters 
Table 2. $\mathrm{H}_{\text {sat }}$ : length of the daily light period during which irradiance at $20 \mathrm{~m}$ water depth in Salt River submarine canyon was above 100 umol quanta $\mathrm{m}^{-2} \mathrm{~s}^{-1}$, the saturation level of Halophila decipiens photosynthesis. $\mathrm{H}_{\mathrm{sai}}=9 \mathrm{~h}$ is the saturation level for growth of $H$. decipiens. Values are percentages of days per month when light was measured on an hourly basis

\begin{tabular}{|c|c|c|c|c|c|c|c|c|c|}
\hline \multirow{3}{*}{ Month } & \multicolumn{9}{|c|}{$\mathrm{H}_{\text {sat }}(\mathrm{h})$} \\
\hline & \multicolumn{5}{|c|}{ Light limitation } & \multicolumn{4}{|c|}{ Saturation } \\
\hline & 4 & 5 & 6 & 7 & 8 & 9 & 10 & 11 & 12 \\
\hline Jan & 0 & 0 & 0 & 0 & 14 & 72 & 14 & 0 & 0 \\
\hline Feb & 0 & 0 & 0 & 0 & 5 & 23 & 69 & 3 & 0 \\
\hline Mar & 0 & 0 & 0 & 0 & 0 & 4 & 13 & 83 & 0 \\
\hline Apr & 0 & 0 & 0 & 0 & 0 & 6 & 6 & 88 & 0 \\
\hline May & 0 & 0 & 0 & 0 & 0 & 0 & 0 & 100 & 0 \\
\hline Jun & 0 & 0 & 0 & 0 & 0 & 0 & 0 & 100 & 0 \\
\hline Jul & 0 & 0 & 0 & 0 & 0 & 0 & 13 & 87 & 0 \\
\hline Aug & 0 & 0 & 0 & 0 & 0 & 0 & 6 & 88 & 6 \\
\hline Oct & 5 & 5 & 0 & 10 & 15 & 20 & 45 & 0 & 0 \\
\hline Nov & 0 & 0 & 6 & 0 & 19 & 75 & 0 & 0 & 0 \\
\hline $\mathrm{Dec}$ & 0 & 0 & 0 & 0 & 33 & 57 & 10 & 0 & 0 \\
\hline
\end{tabular}

tions of $>30 \%$ of macroalgal abundance commonly occur over a wide geographical gradient (e. g. Sears \& Wilce 1975, Prince \& O'Neal 1979, Peckol 1982, Virnstein \& Carbonara 1985, Brouns 1987, Payri 1987). The abundance of marine plants (i. e. density of individuals, coverage, or biomass), is the net effect of biomass accumulation (growth) and removal (disturbance). Temporal variation in abundance occurs when a change in one of these parameters is not compensated for by a change in the other. Given constant disturbance, fluctuations in an environmental condition (e.g. light, temperature, salinity, nutrients) produce temporal changes in growth only when fluctuations occur within: (1) the effective response time of the plant, (2) a critical region that limits plant growth, and (3) outside the range of plant acclimation or ecotypic differentiation. Temporal changes in plant abundance will be irregular when no seasonality is exhibited in factors that limit growth, when seasonal changes fall outside the critical region for growth, or when disturbance does not compensate exactly for changing growth (Doty 1971, Santelices 1977, Dethier 1982). Where changes in factors that limit growth are minimal or outside the critical region, disturbance will have a proportionally greater effect on plant abundances. The myriad factors that affect growth, the types of disturbance, and the interaction between growth and disturbance are represented by a wide variety of habitat-specific temporal patterns in plant abundance.

In Salt River canyon, plant abundances change predictably in winter when storms coincide with light availability that falls into the critical region for growth and thus maintenance of biomass of Halophila decipiens and probably Halimeda incrassata (Figs. 1, 2 and 4; Table 2). Biological disturbances of bioturbation and grazing are not responsible for the seasonal patterns in plant abundance. The coincidence of low light and winter storms similarly controls macroalgal abundance on a sand plain at 10 to $14 \mathrm{~m}$ at Galeta Point, Panama, although the effect of light was not critically assessed (Hay 1981). There grazers are likewise rare. Macroalgal abundance in the intertidal regions of Galeta Point also respond to winter storms that occur during periods of the greatest tidal emersion and thus physiological stress (Kilar \& McLachlan 1986). The habitats discussed above share the feature that times of maximum stress in the form of physiological extremes coincide with abiotic disturbances to control plant abundance, as occurs in temperate rocky intertidal habitats (Dayton 1971, Sousa 1979, Paine \& Levin 1981, Dethier 1984).

In shallow subtidal regions of the same shore of St. Croix as Salt River canyon, factors that affect plant growth, e.g. light and temperature, do not fall into critical limiting regions. I found no significant seasonal patterns in leaf shoot density or growth of seagrasses, or density of Halimeda incrassata and other rhizophytic algae, although plant abundances vary up to $40 \%$ of their yearly maxima (Williams 1987 and unpubl.). Light is sufficient and the physical environment is more benign than that in Salt River canyon. The effects of sea swells and storms are buffered by a barrier reef, and current velocities are reduced by the extensive canopy of seagrass leaves.

In this and other shallow subtidal environments in the Caribbean where the physical environment is comparatively benign and conditions favor high growth rates of plants, disturbance from grazing is a major factor affecting temporal changes in plant abundances (Sammarco et al. 1974, Ogden 1980, Hay 1981, Thayer et al. 1985, Carpenter 1986, Lewis 1986). For example, in a shallow backreef/reef flat on St. Croix, grazers 
consume up to $97 \%$ of the annual algal primary production and algal biomass fluctuates aseasonally throughout the year in response to herbivore abundance rather than algal productivity patterns (Carpenter 1986). In fact, algal biomass increases in November-December when storms and strong swells occur. At this time, light reaches a yearly minimum but is still sufficient for maximum photosynthetic rates (Carpenter 1986).

Grazers remove probably less than $50 \%$ of the primary productivity of seagrass leaves in the Caribbean (Greenway 1976, Ogden 1980). Although estimates of loss of seagrass productivity to grazers are few, grazing in shallow subtidal seagrass beds is unlikely to be as disastrous a disturbance as storms are to the seagrass bed in Salt River canyon. Seagrass leaves regrow from a basal meristem, and the belowground biomass and associated critical nutrient remineralization processes (Klug 1980) are unaffected by grazing.

Only intense, infrequent storms disturb Thalassia spp. and similar shallow water seagrasses because they have massive rhizome systems that are notably resistant to disturbance from waves (Thomas et al. 1961, Birch \& Birch 1984). For example, blowouts (erosional gaps created in a seagrass bed) are restricted to $<4 \mathrm{~m}$ of water, are rare where vegetation is well-developed, and are formed every 5 to $15 \mathrm{yr}$ (Patriquin 1975). Neither the storms of this study nor the record-breaking storms of the century, Hurricanes 'David' and 'Frederick' (1979, pers, obs.) substantially disturbed the shallow seagrass beds on the same shore of St. Croix as Salt River canyon. Hurricanes occur about every 5 to 6 yr (Neumann et al. 1981); significant disturbance to the shallow seagrass beds will occur even less frequently.

Although the deep water seagrass bed in Salt River canyon is disturbed more frequently and intensely (i.e. more biomass, including belowground, is removed) than many shallower seagrass beds, it recovers more rapidly (Patriquin 1975, Zieman 1976, Birch \& Birch 1984, Kirkman 1985). Rapid recovery is possible because: (1) rhizomes of Halophila decipiens branch profusely and grow almost $1 \mathrm{~cm} \mathrm{~d}^{-1}$ in Salt River canyon (Josselyn et al. 1986), (2) sexual reproduction is prolific (see 'Results'), and (3) light, the factor controlling recolonization, increases during each summer to levels allowing effective regrowth. In contrast, shallow water seagrass beds of Syringodium filiforme and Thalassia testudinum are resistant to disturbances from storms but once disturbed, take many years to recolonize areas of only $1 \mathrm{~m}^{2}$ (Patriquin 1975, Zieman 1976, Williams 1985). Rhizomes of $T$. testudinum and $S$. filiforme branch infrequently and grow only a few $\mathrm{mm} \mathrm{d}^{-1}$ (Patriquin 1973,1975$)$. Sexual reproduction of these species is limited to a few months of the year and seedling success is poor (Lewis \& Phillips 1980, McMillan 1981,
Johnson \& Williams 1982, Williams \& Adey 1983). Finally, the slow accumulation of nutrients in the sediments limits the rate of recolonization of shallow $T$. testudinum beds (McRoy \& Lloyd 1981, Williams 1985).

Acknowledgements. I thank the Hydrolab operations staff for assistance during Mission \#84-14 and throughout the project. In particular, I thank aquanauts Dr $M$. Coulston and R. Berey for measuring algal growth. B. Nyden was unfailing in monthly monitoring and the project would have been impossible without him. Drs M. Dethier and S. Woodin kindly commented on the manuscript. This research was supported by the National Undersea Research Program of the National Oceanic \& Atmospheric Administration.

\section{LITERATURE CITED}

Birch, W. R., Birch, M. (1984). Succession and pattern of tropical intertidal seagrasses in Cockle Bay, Queensland. Australia: a decade of observations. Aquat. Bot. 19: 343-367

Brouns, J. J. W. M. (1987). Growth patterns in some IndoWest-Pacific seagrasses. Aquat. Bot. 28:39-61

Carpenter, R. C. (1986). Partitioning herbivory and its effects on coral reef algal communities. Ecol. Monogr. 56: 345-363

Dayton, P. K (1971). Competition, disturbance, and community organization: the provision and subsequent utilization of space in the rocky intertidal community. Ecol. Monogr 41: 351-389

De Kanel, J., Morse, J. W. (1978). The chemistry of orthophosphate uptake from seawater on to calcite and aragonite. Geochim Cosmochim. Acta 42: 1335-1340

den Hartog, C. (1971). The dynamic aspect in the ecology of sea-grass communities. Thalassia jugosl. 7: 101-112

den Hartog, C. (1977). Structure, function, and classification in seagrass communities. In: McRoy, C. P., Helfferich, C. (eds.) A handbook of seagrass biology: an ecosystem perspective. Garland STPM Press, New York, p. 87-116

Dennison, W. C. (1987). Effects of light on seagrass photosynthesis, growth and depth distribution. Aquat. Bot. 27: $15-26$

Dennison, W. C., Alberte, R. S. (1985). Role of daily light period in the depth distribution of Zostera marina (eelgrass). Mar. Ecol. Prog. Ser. 25: 51-61

Dethier, M. N. (1982). Pattern and process in tidepool algae: factors influencing seasonality and distribution. Botanica mar. 25: 55-66

Dethier, M. N. (1984). Disturbance and recovery in intertidal pools: maintenance of mosaic patterns. Ecol. Monogr. 54: 99-118

Doty, M. S. (1971). Antecedent event influence on benthic marine algal standing crops in Hawaii. J. exp. mar. Biol. Ecol. 6: 161-166

Entsch, B., Boto, K. G., Sim, R. G., Wellington, J. T. (1983). Phosphorus and nitrogen in coral reef sediments. Limnol. Oceanogr. 28: 465-476

Greenway, M. (1976). The grazing of Thalassia testudinum in Kingston Harbour, Jamaica. Aquat. Bot. 2: 117-126

Grime, J. P. (1977). Evidence for the existence of three primary strategies in the plants and its relevance to ecological and evolutionary theory. Am. Nat. 111: 1169-1194

Hay, M. E. (1981). Herbivory, algal distribution, and the 
maintenance of between-habitat diversity on a tropical fringing reef. Am. Nat. 118: 520-540

Hillis-Colinvaux, L. (1980). Ecology and taxonomy of Halimeda: primary producer of coral reefs. Adv. mar. Biol. 17: 1-327

Johnson, E. A., Williams, S. L. (1982). Sexual reproduction in seagrasses: reports for five Caribbean species with details for Halodule wrightii Aschers. and Syringodium filiforme Kutz. Carib. J. Sci. 18: 61-70

Josselyn, M. N., Cailliet, G. M., Niesen, T. M., Cowen, R., Hurley, A. C., Connor, J., Hawes, S. (1983). Composition, export and faunal utilization of drift vegetation in Salt River submarine canyon. Estuar. coast. Shelf Sci. 17: $447-465$

Josselyn, M., Fonseca, M., Niesen, T., Larson, R. (1986). Biomass, production and decomposition of a deepwater seagrass, Halophila decipiens Ostenf. Aquat. Bot. 25: 47-61

Kelly, J. A., Fuss, C. M., Hall, J. R. (1971). The transplanting and survival of turtle grass, Thalassia testudinum, in Boca Ciega Bay, Florida. Fish. Bull. U. S. 69: 273-280

Kilar, J. A., McLachlan, J. (1986). Ecological studies of the alga, Acanthophora spicifera (Vahl) Borg. (Ceramiales: Rhodophyta): vegetative fragmentation. J. exp. mar Biol. Ecol. 104: 1-21

Kirkman, H. (1985). Community structure in seagrasses in southern western Australia. Aquat. Bot. 21: 363-375

Klug, M. J. (1980). Detritus-decomposition relationships. In: Phillips, R. C., McRoy, C. P. (eds.) Handbook of seagrass biology: an ecosystem perspective. Garland STPM Press, New York, p. 225-245

LaPointe, B. E. (1986). Phosphorus-limited photosynthesis and growth of Sargassum natans and Sargassum fluitans (Phaeophyceae) in the western North Atlantic. Deep Sea Res. 33: 391-399

LaPointe, B. E. (1987). Phosphorus- and nitrogen-limited photosynthesis and growth of Gracilaria tikvahiae (Rhodophyceae) in the Florida Keys: an experimental field study. Mar. Biol. 93: 561-568

Lewis, R. R., III, Phillips, R. C. (1980). Occurrence of seeds and seedlings of Thalassia testudinum Banks ex Konig in the Florida Keys (USA). Aquat. Bot. 9: 377-380

Lewis, S. M. (1986). The role of herbivorous fishes in the organization of a Caribbean reef community. Ecol. Monogr. 56: 183-200

Lipkin, Y. (1979). Quantitative aspects of seagrass communities, particularly of those dominated by Halophila stipulacea, in Sinai (Northern Red Sea). Aquat. Bot. 7: $119-128$

McMillan, C. (1981). Seed reserves and seed germination for two seagrasses, Halodule wrightii and Syringodium filiforme, from the western Atlantic. Aquat. Bot. 11. 279-296

McRoy, C. P., Lloyd, D. S. (1981). Comparative function and stability of macrophyte-based ecosystems. In: Longhurst, A. R. (eds.) Analysis of marine ecosystems. Academic Press, London, p. 473-489

McRoy, C. P., MCMillan, C. (1977). Productivity and physiological ecology of seagrasses. In: McRoy, C. P., Helfferich, C. (eds.) Seagrass ecosystems: a scientific perspective. M. Dekker, New York, p. 53-88

Neumann, C. J., Cry, G. W., Caso, E. L., Jarvinen, B. R. (1981). Tropical cyclones of the North Atlantic Ocean, 1871-1980. NOAA, Dept of Commerce, Washington, D. C.

Ogden, J. C. (1980). Faunal relationships in Caribbean seagrass beds. In: Phillips, R. C., McRoy, C. P. (eds.) A handbook of seagrass biology. Garland STPM Press, New York, p. $173-198$
Paine, R. T., Levin, S. A. (1981). Intertidal landscapes: disturbance and the dynamics of pattern. Ecol. Monogr 51: $145-178$

Patriquin, D. (1973). Estimation of growth rate, production and age of the marine angiosperm Thalassia testudinum Konig Carib. J. Sci. 13: 111-123

Patriquin, D. G. (1975). 'Migration' of blowouts in seagrass beds at Barbados and Carriacou, West Indies, and its ecological and geological implications. Aquat. Bot. 1: 163-189

Payri, C. E. (1987). Zonation and seasonal variation of the commonest algae on Tiahura Reef (Moorea Island, French Polynesia). Botanica mar. 30: 141-149

Peckol, P. (1982). Seasonal occurrence and reproduction of some marine algae of the continental shelf, North Carolina. Botanica mar. 25: 185-190

Phillips, R. C., Lewis, III, R. L. (1983). Influence of environmental gradients on variations in leaf widths and transplant success in North American seagrasses. Mar. Tech. Soc. J. 17: 59-68

Prince, J. S., O'Neal, S. W. (1979). The ecology of Sargassum pteropleuron Grunow (Phaeophyceae, Fucales) in the waters off South Florida. I. Growth, reproduction and population structure. Phycologia 18: 109-114

Sammarco, P. W., Levinton, J. S., Ogden, J. C. (1974). Grazing and control of coral reef community structure by Diadema antillarum Philippi (Echinodermata: Echinoidea): a preliminary study. J. mar. Res. 32: 31-53

Santelices, B. (1977). Water movement and seasonal algal growth in Hawaii. Mar. Biol. 43: 225-235

Sears, J. R., Wilce, R. T. (1975). Sublittoral, benthic marine algae of southern Cape Cod and adjacent islands: seasonal periodicity, associations, diversity and floristic composition. Ecol. Monogr. 45: 337-365

Short, F. T., Davis, M. W., Gibson, R. A., Zimmerman, C. F. (1985). Evidence for phosphorus limitation in carbonate sediments of the seagrass Syringodium filiforme. Estuar coast. Shelf Sci. 20: 419-430

Sousa, W. P. (1979). Experimental investigations of disturbance and ecological succession in a rocky intertidal algal community. Ecol. Monogr. 49: 227-254

Thayer, G. W., Bjorndal, K. A., Ogden, J. C., Williams, S. L. Zieman, J. C. (1985). Role of large herbivores on seagrass communities. Estuaries 7: 351-376

Thomas, L. P., Moore, D. R., Work, R. C. (1961). Effects of Hurricane Donna on the turtle grass beds of Biscayne Bay, Florida. Bull. mar Sci. Gulf Carib. 11: 191-197

Virnstein, R. W., Carbonara, P. A. (1985). Seasonal abundance and distribution of drift algae and seagrasses in the midIndian River lagoon, Florida. Aquat. Bot. 23: 67-82

Williams, S. L. (1981). Caulerpa cupressoides: the relationship of the uptake of sediment ammonium and of algal decomposition to seagrass bed colonization. Ph. D. dissertation, Univ. Maryland, College Park

Williams, S. L. (1984). Uptake of sediment ammonium and translocation in a marine green macroalga Caulerpa cupressoides. Limnol. Oceanogr. 29: 374-379

Williams, S. L. (1985). Factors affecting seagrass recolonization. Estuaries 8: $16 \mathrm{~A}$

Williams, S. L. (1987). Competition between the seagrasses Thalassia testudinum and Syringodium filiforme in a Caribbean lagoon. Mar. Ecol. Prog. Ser 35: 91-98

Williams, S. L., Adey, W H. (1983). Thalassia testudinum Banks ex Konig seedling success in a coral reef microcosm. Aquat. Bot. 16: 181-188

Williams, S. L., Breda, V. A., Anderson, T W., Nyden, B. B (1985a). Growth and sediment disturbances of Caulerpa 
spp. (Chlorophyta) in a submarine canyon. Mar. Ecol. Prog. Ser. 21: 275-281

Williams, S. L., Yarish, S. M., Gill, I. P. (1985b). Ammonium distributions, production, and efflux from backreef sediments, St. Croix, US Virgin Islands. Mar. Ecol. Prog. Ser. 24: $57-64$

Zieman, J. C. (1976). The ecological effects of physical dam- age from motor boats on turtle grass beds in southern Florida. Aquat. Bot. 2: 127-139

Zieman, J. C., Wetzel, R. G. (1980). Productivity in seagrasses: methods and rates. In: Phillips, R. C., McRoy, C. P. (eds.) A handbook of seagrass biology: an ecosystem perspective. Garland STPM Press, New York, p. 87-116

This article was presented by Dr G. W. Thayer; it was accepted for printing on October 5, 1987 